Review

\title{
Dietary Patterns, Alcohol Consumption and Risk of Coronary Heart Disease in Adults: A Meta-Analysis
}

\author{
Xiao-Yan Zhang ${ }^{1}$, , Long Shu ${ }^{1}$, Cai-Juan Si ${ }^{1}$, Xiao-Long Yu ${ }^{1}$, Dan Liao ${ }^{1}$, Wei Gao ${ }^{1}$, \\ Lun Zhang ${ }^{1}$ and Pei-Fen Zheng ${ }^{1,2}$ \\ ${ }^{1}$ Department of Nutrition, Zhejiang Hospital, Hangzhou 310013, China; \\ E-Mails: shulong19880920@126.com (L.S.); xiaosi_32075001@126.com (C.-J.S.); \\ xly2008hi@163.com (X.-L.Y.); liaodan0203@sina.com (D.L.); gaowei05715133@163.com (W.G.); \\ zhanglun306@163.com (L.Z.); kuaidou09@163.com (P.-F.Z.) \\ ${ }^{2}$ Department of Digestion, Zhejiang Hospital, Hangzhou 310013, China \\ * Author to whom correspondence should be addressed; E-Mail: zxy19740804@ sina.com; \\ Tel.: +86-571-8798-5133; Fax: +86-571-8798-0175.
}

Received: 27 May 2015 / Accepted: 24 July 2015 / Published: 7 August 2015

\begin{abstract}
Previous studies reported the potential associations between dietary patterns and the risk of coronary heart disease (CHD) in adulthood, however a consistent perspective has not been established to date. Herein, we carried out this meta-analysis to evaluate the associations between dietary patterns and the risk of CHD. MEDLINE and EBSCO were searched for relevant articles published up to April 2015. A total of 35 articles (reporting 37 original studies) met the inclusion criteria and were included in the present meta-analysis. The decreased risk of CHD was shown for the highest compared with the lowest categories of healthy/prudent dietary patterns (odds ratio $(\mathrm{OR})=0.67 ; 95 \%$ confidence interval $(\mathrm{CI})$ : 0.60 , $0.75 ; p<0.00001$ ) and alcohol consumption (OR $=0.68 ; 95 \% \mathrm{CI}: 0.59,0.78 ; p<0.00001$ ). There was evidence of an increased risk of CHD in the highest compared with the lowest categories of the unhealthy/Western-type dietary patterns (OR $=1.45 ; 95 \% \mathrm{CI}: 1.05,2.01$; $p=0.02$ ). The results of this meta-analysis indicate that different dietary patterns may be associated with the risk of CHD.
\end{abstract}

Keywords: dietary patterns; coronary heart disease; a meta-analysis 


\section{Introduction}

Although the incidence and mortality of coronary heart disease (CHD) have decreased in the United States and Western Europe since 1970s, it remains the leading cause of death globally, with 7.2 million deaths occurring worldwide every year [1-3]. In China, the prevalence of CHD surpassed 80 million by 2010, and every year it causes death in over one million people [4,5]. It is well-known that CHD is considered as a multifactorial chronic disease that may be associated with hypertension, dyslipidemia, impaired glucose tolerance, smoking, genetic factors, and dietary factors [6-8].

In the past few decades, many studies particularly focused on diet modification as an important determinant in the development of CHD and found associations between the intakes of individual foods or nutrients and the risk of CHD. However, in reality, people generally do not take nutrients alone but consume meals containing many combinations of foods and nutrients [9]. Consequently, the analysis of dietary patterns has been increasingly used in nutritional epidemiology, taking into account the combined effects of foods, and potentially facilitating nutritional recommendations [10].

Recently, an emerging body of evidence has suggested that there has been considerable attention in epidemiological research on the associations between overall dietary patterns and the risk of CHD [11-23]. Nevertheless, the results of dietary patterns and CHD risk are inconsistent. Although some studies reported positive associations between Western/unhealthy dietary patterns and the risk of CHD [14,19,22], others showed no significant association [12]. Therefore, we conducted a meta-analysis of studies published up to April 2015, to further identify the potential associations between dietary patterns and the risk of CHD.

\section{Methods}

\subsection{Literature Search Strategy}

An electronic literature search was conducted in MEDLINE and EBSCO to identify human studies written in English or Chinese, published up to April 2015, with the following keywords: dietary pattern, dietary patterns, alcohol drinking, alcohol consumption, cardiovascular disease, ischemic heart disease, myocardial infarction, coronary heart disease and coronary diseases. In addition, we manually searched all references cited in original studies and reviews identified.

\subsection{Study Included Criteria}

Two independent reviewers (L. Shu and X.-Y. Zhang) read the abstracts of the papers retrieved in the initial search to identify studies that examined the associations between dietary patterns and the risk of CHD. When all reviewers agreed, the papers were reviewed against inclusion and exclusion criteria for this meta-analysis. To be eligible, dietary pattern studies had to fulfill the following criteria: (1) The study was published as an original article reporting the relationship of different dietary patterns and the risk of CHD. (2) Food or dietary patterns in studies were examined by principal component analysis (PCA) and/or factor analysis (FA). (3) Odds ratios or hazard ratios, and percentage for CHD (or data can be calculated) had been provided. (4) CHD was diagnosed based on clinical manifestations (including myocardial infarction or angina, or myocardial ischemia, or cardiac failure and arrhythmia, or a death 
certificate cause of death as CHD), electrocardiogram, and coronary aeteriography. Alcohol studies were included in this meta-analysis if they met the following criteria: (1) the study was published as an original article; (2) the association between alcohol intake and risk of CHD had been reported in studies; (3) the different alcohol consumption categories have been described in studies; and (4) CHD was diagnosed based on clinical manifestations, electrocardiogram, and coronary arteriography.

\subsection{Data Extraction}

Information extracted from each study included authors, geographic region, study design, sample size, the number of CHD, dietary assessment method, identification of dietary patterns, and factors that were adjusted in the including studies.

\subsection{Definition of "High Intake"}

Dietary patterns were identified by principal component analysis or factor analysis. Factor scores for each pattern were categorized into tertiles, quartiles, or quintiles (the lowest category and the highest category represented low and high intake, respectively, to each dietary pattern.) The different forms of alcohol consumption were converted into grams of ethanol per day. Alcohol consumption of $>25 \mathrm{~g} / \mathrm{day}$ for men or $>12.5 \mathrm{~g} /$ day for women was defined as a high intake of alcohol or heavy alcohol drinking; alcohol consumption of $<12.5 \mathrm{~g} /$ day for men or $<7.5 \mathrm{~g} /$ day for women was defined as a low intake of alcohol, and alcohol consumption of $>12.5 \mathrm{~g} /$ day and $<25 \mathrm{~g} /$ day for men or $>7.5 \mathrm{~g} /$ day and $<12.5 \mathrm{~g} /$ day for women was defined as a moderate alcohol consumption [24].

\subsection{Quality Assessment}

The Newcastle-Ottawa Quality Assessment scale was used for quality assessment [25]. Eight questions were assessed and each satisfactory answer received one point (may receive two points in comparability categories), resulting in a maximum score of nine. Only those studies in which most the questions were deemed satisfactory (i.e., with a score of six or higher) were considered to be of high methodological quality.

\subsection{Assessment of Heterogeneity}

Heterogeneity of the study results was estimated by the chi-squared test. $p$ Values less than 0.05 were considered to be significant. In this meta-analysis, a random-effects model was used to account for possible heterogeneity between studies, while a fixed-effects model was adopted in the absence of heterogeneity [26].

\subsection{Statistical Analysis}

Statistical analyses were performed using Review Manager, version 5.0 (Nordic Cochrane Centre, Copenhagen, Denmark) and STATA software, version 12.0 (Stata Corp, College Station, TX, USA). The original studies reported the results of dietary patterns or alcohol consumption in terms of quintiles, quartiles, and tertiles of dietary factor scores and the risk of CHD. We used meta-analysis to evaluate the risk of CHD in the highest versus the lowest categories of healthy/prudent, unhealthy/Western-type 
dietary patterns and alcohol consumption. Random-effect models were used to calculate the pooled odd ratio (OR) for dietary patterns in highest categories compared with lowest categories. Raw data from individual studies were weighted and combined to produce an overall OR. Publication bias was assessed by inspection of the funnel plot and by formal testing for "funnel plot" asymmetry using Begg's test and Egger's test [27]. All statistical tests were two-sided and $p$ values less than 0.05 were considered significant.

\section{Results}

\subsection{Overview of Included Studies for the Systematic Meta-Analysis}

An electronic literature search in the database of MEDLINE and EBSCO identified 560 studies, 525 of which were excluded based on the reasons listed in Figure 1: meta-analysis, reviews or systematic reviews $(n=173)$; title and abstract did not contain the data on classification of dietary pattern or alcohol consumption $(n=278)$; did not provide sufficient dichotomous data on dietary pattern and CHD $(n=25)$; focused on single nutrients or food $(n=18)$; did not provide the data about percent of CHD or number of each group $(n=20)$; reported data using different alcohol consumption categories $(n=10)$; and reported the same data $(n=1)$. At last, 35 articles [8,11,13-23,28-49] (reporting 37 original studies) met the inclusion criteria and were included in this meta-analysis. Descriptive information of each included study was presented in Table 1.

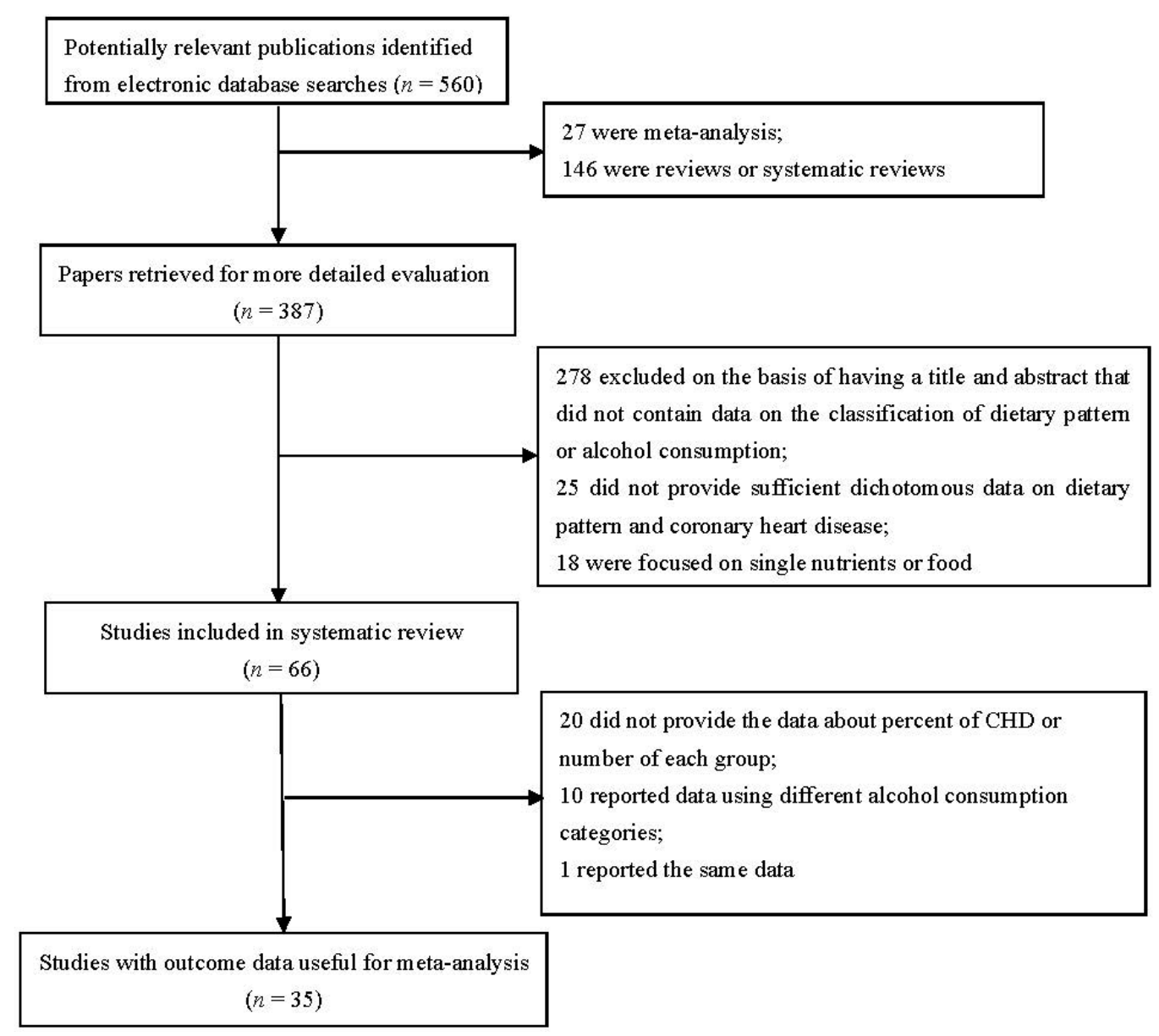

Figure 1. Flow chart of article screening and selection process. 
Table 1. Characteristics of 35 studies included in the meta-analysis (1991-2015).

\begin{tabular}{|c|c|c|c|c|c|c|c|}
\hline $\begin{array}{c}\text { Author and } \\
\text { Publication Year }\end{array}$ & Location & $\begin{array}{l}\text { Study } \\
\text { Design }\end{array}$ & $\begin{array}{l}\text { Total } \\
\text { Number of } \\
\text { Subjects }\end{array}$ & Age (Year)/Sex & $\begin{array}{l}\text { Diet } \\
\text { Assessment } \\
\text { Method }\end{array}$ & $\begin{array}{l}\text { Dietary Patterns } \\
\text { Identified }\end{array}$ & Factors Adjusted for in Analyses \\
\hline $\begin{array}{c}\text { Osler et.al., } \\
2002[8]\end{array}$ & Danish & Cohort & 5834 & 30-60 years both & FFQ & $\begin{array}{l}\text { "prudent food" } \\
\text { "Western food" }\end{array}$ & $\begin{array}{l}\text { Smoking, exercise, education, BMI and } \\
\text { alcohol intake }\end{array}$ \\
\hline $\begin{array}{l}\text { Fung et.al., } \\
2001[11]\end{array}$ & US & Cohort & 69,017 & $38-63$ years women & FFQ & $\begin{array}{l}\text { "Prudent" } \\
\text { "Western" }\end{array}$ & $\begin{array}{l}\text { Age, period, smoking, BMI, hormone } \\
\text { replacement therapy, aspirin use, caloric intake, } \\
\text { family history, history of hypertension, } \\
\text { multivitamin and vitamin E supplement use, } \\
\text { physical activity }\end{array}$ \\
\hline $\begin{array}{l}\text { Iqbal et.al., } \\
2008[13]\end{array}$ & $\begin{array}{c}52 \\
\text { countries }\end{array}$ & Case-control & $5761 / 10,646$ & 41-70 years both & FFQ & $\begin{array}{c}\text { Oriental, Western, } \\
\text { prudent }\end{array}$ & $\begin{array}{l}\text { Age, sex, region, education, BMI, physical } \\
\text { activity, smoking }\end{array}$ \\
\hline $\begin{array}{l}\text { Hoffmann et.al., } \\
\qquad 2004 \text { [14] }\end{array}$ & Germany & Case-control & $200 / 255$ & 30-80 years women & FFQ & "Western" & $\begin{array}{l}\text { Age, cigarette smoking, hormone replacement } \\
\text { therapy, hypertension, education level, physical } \\
\text { activity level and sport }\end{array}$ \\
\hline $\begin{array}{l}\text { Stricker et.al., } \\
\quad 2012[15]\end{array}$ & Dutch & Cohort & 40,011 & $50-69$ years both & FFQ & $\begin{array}{l}\text { "Prudent" } \\
\text { "Western" }\end{array}$ & $\begin{array}{l}\text { Age, gender, physical activity, smoking status, } \\
\text { education, systolic- and diastolic blood } \\
\text { pressure and energy intake }\end{array}$ \\
\hline $\begin{array}{c}\text { Weikert } \\
\text { et.al., [16] } \\
\text { (CORA) 2005 }\end{array}$ & Germany & Case-control & $200 / 255$ & 30-80 years women & FFQ & $\begin{array}{l}\text { "Simplified food } \\
\text { pattern" }\end{array}$ & $\begin{array}{l}\text { Age, cigarette smoking, education attainment, } \\
\text { BMI, physical activity level, total energy } \\
\text { intake, hormone replacement therapy, } \\
\text { hypertension, dyslipidemia, and diabetes }\end{array}$ \\
\hline $\begin{array}{c}\text { Weikert } \\
\text { et.al., [16] } \\
\text { (EPIC-Potsdam) } \\
2005 \\
\end{array}$ & Germany & Cohort & 26,795 & $35-65$ years both & FFQ & $\begin{array}{l}\text { "Simplified food } \\
\text { pattern" }\end{array}$ & $\begin{array}{l}\text { Age, cigarette smoking, education attainment, } \\
\text { BMI, physical activity level, total energy } \\
\text { intake, hormone replacement therapy, } \\
\text { hypertension, dyslipidemia, and diabetes }\end{array}$ \\
\hline $\begin{array}{l}\text { Lipoeto et.al., } \\
2004 \text { [17] }\end{array}$ & Indonesia & Case-control & $93 / 189$ & men and women & FFQ & "Animal foods" & $\begin{array}{l}\text { Age, physical activity and stress } \\
\text { level, total energy }\end{array}$ \\
\hline
\end{tabular}


Table 1. Cont.

\begin{tabular}{|c|c|c|c|c|c|c|c|}
\hline $\begin{array}{c}\text { Tucker et.al., } \\
2005 \text { [18] }\end{array}$ & US & Cohort & 501 & $34-80$ years men & $\begin{array}{l}\text { 7-day diet } \\
\text { records }\end{array}$ & $\begin{array}{c}\text { "Low SF and high } \\
\text { FV" }\end{array}$ & $\begin{array}{l}\text { Age,, total energy intake, BMI, smoking, } \\
\text { alcohol use, physical activity score, dietary } \\
\text { supplement use }\end{array}$ \\
\hline $\begin{array}{l}\text { McNaughton } \\
\text { et.al., } 2009 \text { [19] }\end{array}$ & UK & Cohort & 7314 & $35-55$ years both & FFQ & $\begin{array}{l}\text { "Dietary pattern 1" } \\
\text { "Dietary pattern 2" }\end{array}$ & $\begin{array}{l}\text { Age, sex, energy misreporting, ethnicity, } \\
\text { smoking, alcohol, physical activity, blood } \\
\text { pressure and BMI }\end{array}$ \\
\hline $\begin{array}{l}\text { Fitzgerald et.al., } \\
\qquad 2012 \text { [20] }\end{array}$ & US & Cohort & 34,827 & $\geqslant 45$ years women & FFQ & "DASH" & $\begin{array}{l}\text { Randomization status, age, smoking, } \\
\text { time-varying postmenopausal status, } \\
\text { time-varying hormone therapy use, alcohol } \\
\text { intake, energy intake, physical activity, } \\
\text { cigarettes per day, BMI, and highest education } \\
\text { level }\end{array}$ \\
\hline $\begin{array}{l}\text { Martínez-Gonzlez } \\
\text { et.al., } 2011 \text { [21] }\end{array}$ & Spain & Cohort & 13,609 & $34-43$ years both & FFQ & "Mediterranean" & $\begin{array}{l}\text { Age, sex, family history of coronary heart } \\
\text { disease, total energy intake, physical activity, } \\
\text { smoking, BMI, diabetes at baseline, use of } \\
\text { aspirin, history of hypertension and history of } \\
\text { hypercholesterolemia }\end{array}$ \\
\hline $\begin{array}{l}\text { Maruyama et.al., } \\
2013 \text { [22] }\end{array}$ & Japan & Cohort & 64,037 & 40-79 years both & FFQ & $\begin{array}{l}\text { "Vegetable" } \\
\text { "Animal food" } \\
\text { "Dairy product" }\end{array}$ & $\begin{array}{l}\text { Age, BMI, smoking category, walking time, } \\
\text { hours of sports, perceived mental stress, total } \\
\text { energy intake, history of hypertension and } \\
\text { diabetes }\end{array}$ \\
\hline $\begin{array}{l}\text { Hu et.al., } \\
2000[23]\end{array}$ & US & Cohort & 44,874 & 40-75 years men & FFQ & $\begin{array}{l}\text { "Prudent", } \\
\text { "Western" }\end{array}$ & $\begin{array}{l}\text { Age, BMI, time period, cigarette smoking, } \\
\text { parental history of myocardial infarction before } \\
\text { age } 60 \text {, multivitamin and vitamin E supplement } \\
\text { use, alcohol consumption, history of } \\
\text { hypertension, physical activity, total energy } \\
\text { intake, and profession }\end{array}$ \\
\hline
\end{tabular}


Table 1. Cont.

\begin{tabular}{|c|c|c|c|c|c|c|c|}
\hline $\begin{array}{l}\text { Guallar-Castillón } \\
\text { et.al., } 2012 \text { [28] }\end{array}$ & Spain & Cohort & 40,757 & 29-69 years both & $\begin{array}{l}\text { Dietary } \\
\text { history }\end{array}$ & $\begin{array}{l}\text { "Mediterranean", } \\
\text { "Westernized" }\end{array}$ & $\begin{array}{l}\text { BMI, waist circumference, education, smoking, } \\
\text { physical activity at work, physical activity at } \\
\text { home, physical activity during leisure time, } \\
\text { diabetes, hypertension, hypercholesterolemia, } \\
\text { cancer, oral contraceptives, menopausal status, } \\
\text { hormone replacement therapy, total energy } \\
\text { intake, and stratified by age at recruitment, sex, } \\
\text { and center. }\end{array}$ \\
\hline $\begin{array}{l}\text { Martínez-González } \\
\text { et.al., 2002 [29] }\end{array}$ & Spain & Case-control & $171 / 171$ & $\leqslant 80$ years both & FFQ & $\begin{array}{l}\text { "Priori pattern" } \\
\text { "Mediterranean" } \\
\text { "Post hoc pattern" }\end{array}$ & $\begin{array}{l}\text { Smoking, BMI, high blood pressure, high } \\
\text { blood cholesterol, diabetes, leisure-time } \\
\text { activity, family history of CHD before } 60 y \text {, } \\
\text { aspirin intake and socioeconomic status }\end{array}$ \\
\hline $\begin{array}{l}\text { Shimazu et.al., } \\
2007 \text { [30] }\end{array}$ & Japan & Cohort & 40,547 & 40-79 years both & FFQ & $\begin{array}{l}\text { "Japanese pattern" } \\
\text { "Animal food" }\end{array}$ & $\begin{array}{l}\text { Age, sex, smoking status, walking duration, } \\
\text { education, total energy intake, BMI, and } \\
\text { history of hypertension }\end{array}$ \\
\hline $\begin{array}{c}\text { Arriola et.al., } \\
2010[31]\end{array}$ & Spain & Cohort & 41,438 & 29-69 years both & $\begin{array}{l}\text { Dietary } \\
\text { history } \\
\text { questionnaire }\end{array}$ & Alcohol intake & $\begin{array}{l}\text { Centre, smoking status, height and educational } \\
\text { level, stratified by age, physical activity index, } \\
\text { waist/hip ratio, vitamin E, antithrombotic and } \\
\text { antihemorrhagic drugs and energy intake }\end{array}$ \\
\hline $\begin{array}{l}\text { Beulens et.al., } \\
2007 \text { [32] }\end{array}$ & US & Cohort & 11,711 & 40-75 years men & FFQ & Alcohol intake & $\begin{array}{l}\text { Age, smoking, BMI, physical activity, diabetes, } \\
\text { hypercholesterolemia, family history of MI, } \\
\text { aspirin use, lipid-lowering therapy, energy } \\
\text { intake, and energy-adjusted quintiles of } \\
\text { saturated fat, trans fatty acids, sodium, } \\
\text { potassium, magnesium, folate, vitamin E, n-3 } \\
\text { fatty acids, and dietary fiber. }\end{array}$ \\
\hline
\end{tabular}


Table 1. Cont.

\begin{tabular}{|c|c|c|c|c|c|c|c|}
\hline $\begin{array}{l}\text { Bos et.al., } \\
2010[33]\end{array}$ & Dutch & Cohort & 10,530 & $\begin{array}{c}\text { 49-70 years } \\
\text { women }\end{array}$ & FFQ & Alcohol intake & $\begin{array}{l}\text { Age, smoking, BMI, menopausal status, } \\
\text { physical activity, education level, } \\
\text { hypercholesterolemia, diabetes, } \\
\text { antihypertensive medication, daily energy } \\
\text { intake, vitamin E, vitamin C, saturated fat, and } \\
\text { fiber intake }\end{array}$ \\
\hline $\begin{array}{l}\text { Fernández-Jarne } \\
\text { et.al., } 2003 \text { [34] }\end{array}$ & Spain & Case-control & $171 / 171$ & $\begin{array}{c}\text { Mean } 62 \text { years } \\
\text { Both }\end{array}$ & FFQ & Total alcohol intake & $\begin{array}{l}\text { Total energy intake, smoking, BMI, high blood } \\
\text { pressure, high blood cholesterol, diabetes, } \\
\text { leisure-time physical activity, aspirin use, } \\
\text { family history of coronary heart disease, } \\
\text { marital status, occupation, study level, olive oil } \\
\text { consumption, ratio of monounsaturated to } \\
\text { saturated fat, folic acid, and total fiber intake. }\end{array}$ \\
\hline $\begin{array}{c}\text { Fuchs et.al., } \\
2004 \text { [35] }\end{array}$ & US & Cohort & 14,506 & $\begin{array}{c}\text { 45-64 years } \\
\text { men }\end{array}$ & $\begin{array}{c}\text { Dietary } \\
\text { questionnaire }\end{array}$ & Alcohol intake & $\begin{array}{l}\text { Age, cigarette-years of smoking, BMI, } \\
\text { LDL- and HDL-cholesterol level, waist/hip } \\
\text { ratio, educational level, income, sport index, } \\
\text { diabetes mellitus, systolic blood pressure, use } \\
\text { of antihypertensive medication. }\end{array}$ \\
\hline $\begin{array}{c}\text { Ikehara et.al., } \\
2009 \text { [36] }\end{array}$ & Japan & Cohort & 19,356 & $\begin{array}{c}\text { 40-69 years } \\
\text { men }\end{array}$ & $\begin{array}{l}\text { Self-administered } \\
\text { questionnaire }\end{array}$ & $\begin{array}{c}\text { d Alcohol } \\
\text { consumption }\end{array}$ & $\begin{array}{l}\text { Age, smoking status, body mass index, history } \\
\text { of hypertension and diabetes, sports of leisure } \\
\text { time, levels of mental stress, presence of } \\
\text { flushing and job, marital status, medical } \\
\text { checkups and area. }\end{array}$ \\
\hline $\begin{array}{c}\text { Ikehara et.al., } \\
2008 \text { [37] }\end{array}$ & Japan & Cohort & 83,682 & $\begin{array}{c}40-79 \text { years } \\
\text { both }\end{array}$ & $\begin{array}{l}\text { Self-administered } \\
\text { questionnaire }\end{array}$ & Ethanol intake & $\begin{array}{l}\text { Age, smoking status, BMI, history of } \\
\text { hypertension and diabetes, frequency of } \\
\text { exercise, perceived mental stress, education } \\
\text { level, and intake of vegetables, fish, and fruit }\end{array}$ \\
\hline
\end{tabular}


Table 1. Cont.

\begin{tabular}{|c|c|c|c|c|c|c|c|}
\hline $\begin{array}{c}\text { Ikehara et.al., } \\
2013 \text { [38] }\end{array}$ & Japan & Cohort & 47,100 & 40-69 years women & $\begin{array}{l}\text { Self-reported } \\
\text { questionnaire }\end{array}$ & $\begin{array}{c}\text { Alcohol } \\
\text { consumption }\end{array}$ & $\begin{array}{l}\text { Age, smoking status, body mass index, } \\
\text { history of diabetes, sports at leisure time, } \\
\text { flushing after drinking alcohol, mental stress, } \\
\text { menopausal status and area, history of } \\
\text { hypertension }\end{array}$ \\
\hline $\begin{array}{c}\text { Mukamal et.al., } \\
2006 \text { [39] }\end{array}$ & US & Cohort & 38,077 & $40-75$ years men & FFQ & $\begin{array}{l}\text { Alcohol } \\
\text { consumption }\end{array}$ & $\begin{array}{l}\text { Age, smoking status, body mass index, the } \\
\text { presence or absence of diabetes, } \\
\text { hypertension, hypercholesterolemia, and a } \\
\text { parental history of myocardial infarction, use } \\
\text { or nonuse of aspirin, physical activity, intake } \\
\text { of energy, and energy-adjusted intake of } \\
\text { folate, vitamin E, saturated fat, trans fat, and } \\
\text { fiber. }\end{array}$ \\
\hline $\begin{array}{c}\text { Keil et.al., } \\
1997 \text { [40] }\end{array}$ & Germany & Cohort & $62 / 1071$ & 45-64 years both & 7-day recall & Alcohol intake & Age, smoking, hypertension, BMI \\
\hline $\begin{array}{c}\text { Kono et.al., } \\
1991 \text { [41] }\end{array}$ & Japan & Case-control & $89 / 271$ & 40-69 years both & $\begin{array}{l}\text { Self-administered } \\
\text { questionnaire }\end{array}$ & Alcohol intake & $\begin{array}{l}\text { Age, smoking, strenuous exercise, BMI, } \\
\text { systemic hypertension, diabetes mellitus, } \\
\text { heart disease in parent, job class }\end{array}$ \\
\hline $\begin{array}{c}\text { Schröder et.al., } \\
2007 \text { [42] }\end{array}$ & Spain & Case-control & $224 / 1270$ & $25-74$ years both & Questionnaire & Alcohol intake & $\begin{array}{l}\text { Age, smoking, educational level, leisure-time } \\
\text { physical activity, total cholesterol, LDL- and } \\
\text { HDL-cholesterol, diabetes, } \\
\text { hypercholesterolemia drug treatment, and } \\
\text { diagnosed hypertension }\end{array}$ \\
\hline $\begin{array}{l}\text { Wells et.al., } \\
2004 \text { [43] }\end{array}$ & $\begin{array}{c}\text { New } \\
\text { Zealand }\end{array}$ & Case-control & $1381 / 1892$ & $35-74$ years both & Questionnaire & Alcohol intake & $\begin{array}{l}\text { Age group, history of CHD, tobacco } \\
\text { smoking, leisure-time physical activity, } \\
\text { current antihypertensive drug treatment, } \\
\text { family history of premature cardiovascular } \\
\text { disease, BMI, diabetes, socioeconomic status, } \\
\text { income and low education. }\end{array}$ \\
\hline
\end{tabular}


Table 1. Cont.

\begin{tabular}{|c|c|c|c|c|c|c|c|}
\hline $\begin{array}{c}\text { Kitamura et.al., } \\
1998 \text { [44] }\end{array}$ & Japan & Cohort & 8476 & $40-59$ years men & Interview & Alcohol intake & $\begin{array}{l}\text { Age, serum total cholesterol, cigarette } \\
\text { smoking, BMI, left ventricular } \\
\text { hypertrophy, and history of diabetes } \\
\text { mellitus. }\end{array}$ \\
\hline $\begin{array}{l}\text { Mukamal et.al., } \\
2006(n=2)[45]\end{array}$ & US & Cohort & 4410 & $\geqslant 65$ years both & $\begin{array}{l}\text { Self-administered } \\
\text { questionnaire }\end{array}$ & Alcohol use & $\begin{array}{l}\text { Age, sex, race, education, marital status, } \\
\text { smoking, exercise intensity, depression } \\
\text { score, frequent aspirin use, BMI, and } \\
\text { diabetes mellitus. }\end{array}$ \\
\hline $\begin{array}{l}\text { Solomon et.al., } \\
2000[46]\end{array}$ & US & Cohort & 5103 & $30-55$ years women & FFQ & $\begin{array}{c}\text { Alcohol } \\
\text { consumption }\end{array}$ & $\begin{array}{l}\text { Age, time period, body mass index, } \\
\text { cigarette smoking, parental history of MI } \\
\text { before age } 60 \text { years, hypertension, } \\
\text { hypercholesterolemia, menopausal } \\
\text { status/postmenopausal hormone use, } \\
\text { aspirin use, multivitamin use, vitamin E } \\
\text { supplement use, and physical activity } \\
\text { level. }\end{array}$ \\
\hline $\begin{array}{l}\text { Bazzano et.al., } \\
2009 \text { [47] }\end{array}$ & China & Cohort & 64,597 & $\geqslant 40$ years men & $\begin{array}{l}\text { Interviewer-administered } \\
\text { questionnaire }\end{array}$ & $\begin{array}{l}\text { d Alcohol } \\
\text { consumption }\end{array}$ & $\begin{array}{l}\text { Age, body-mass index, average systolic } \\
\text { blood pressure, physical activity, cigarette } \\
\text { smoking, diabetes education, urban or } \\
\text { rural residence, and living in North China }\end{array}$ \\
\hline $\begin{array}{l}\text { Hvidtfeldt et.al., } \\
\quad 2010 \text { [48] }\end{array}$ & Denmark & Cohort & 266,986 & $\geqslant 39$ years both & $\begin{array}{c}\text { FFQ or diet } \\
\text { history } \\
\text { questionnaire }\end{array}$ & Alcohol intake & Age, year of baseline questionnaire \\
\hline $\begin{array}{l}\text { Rajpathak et.al., } \\
2010 \text { [49] }\end{array}$ & US & Cohort & 3198 & 50-79 years women & FFQ & Alcohol intake & $\begin{array}{l}\text { Age, race/ethnicity, BMI, smoking, } \\
\text { hypertension, high cholesterol, hormone } \\
\text { use, regular aspirin use, quintiles of } \\
\text { physical activity, duration of DM, intake } \\
\text { of saturated fat, PUFA, fiber. }\end{array}$ \\
\hline
\end{tabular}

BMI: body mass index; CHD: coronary heart disease; LDL-cholesterol: low-density lipoproteins cholesterol; HDL-cholesterol: high-density lipoproteins cholesterol;

WHR: waist hip ratio; FFQ: food frequency questionnaire. 


\subsection{Healthy Dietary Pattern}

The healthy/prudent dietary patterns were characterized by high consumption of vegetables, fruits, whole grains, olive oil, fish, soy, poultry and low fat dairy. The examined studies labeled it as "Prudent" [8,11,13,15,23], "Simplified food" [16], "Low SF and high FV" [18], "Dietary pattern 1" [19], "DASH" [20], "Mediterranean" [21,28,29], "Vegetable and fruit" [22], and "Japanese pattern" [30]. Figure 2 showed an obvious evidence of a decreased risk of CHD in the highest compared with the lowest categories of "healthy/prudent dietary patterns ( $\mathrm{OR}=0.67$; CI: $0.60,0.75 ; p<0.00001)$. A random-effects model was used to assess the data included in our analyses. The heterogeneity was apparent in all the studies $\left(p=0.004 ; I^{2}=57 \%\right)$.

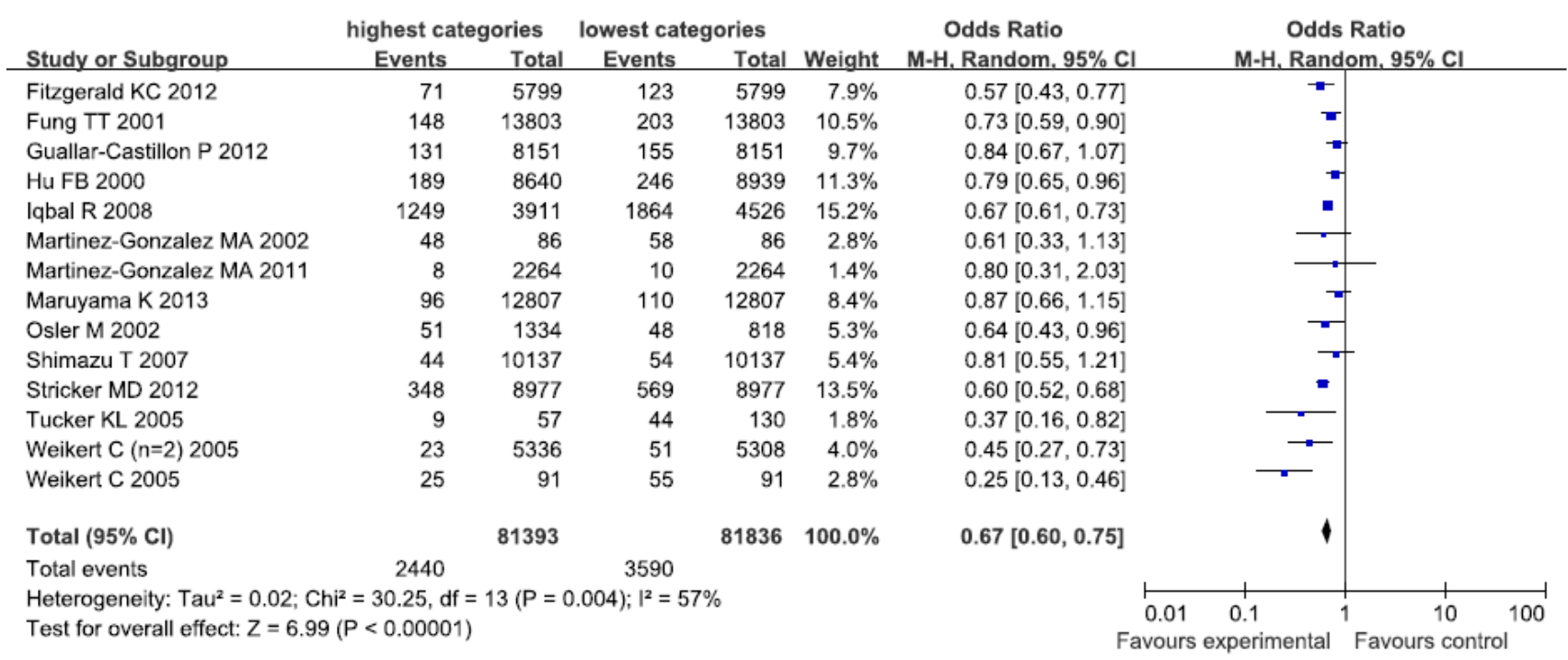

Figure 2. Forest plot of the highest compared with the lowest categories of intake of the healthy/prudent dietary patterns and coronary heart disease (CHD) risk.

\subsection{Western-Type Dietary Pattern}

The unhealthy/Western-type dietary patterns were characterized by high consumption of red and/or processed meat, refined grains, sweets, high-fat dairy products, butter, potatoes and high-fat gravy, and low intakes of fruits and vegetables. The studies under consideration labeled it as "Western" [8,9,13-15,23,28], "Animal foods" [17,22,30] and "Dietary pattern 2" [19]. The association between unhealthy/Western-type dietary patterns and the risk of CHD was shown in Figure 3. There was evidence of an increased risk of CHD in the highest compared with the lowest categories of unhealthy/Western-type dietary patterns ( $\mathrm{OR}=1.45$; CI: $1.05,2.01 ; p=0.02$ ) where all studies were combined in the random-effects model. There was significant heterogeneity $\left(I^{2}=96 \%, p<0.00001\right)$. 


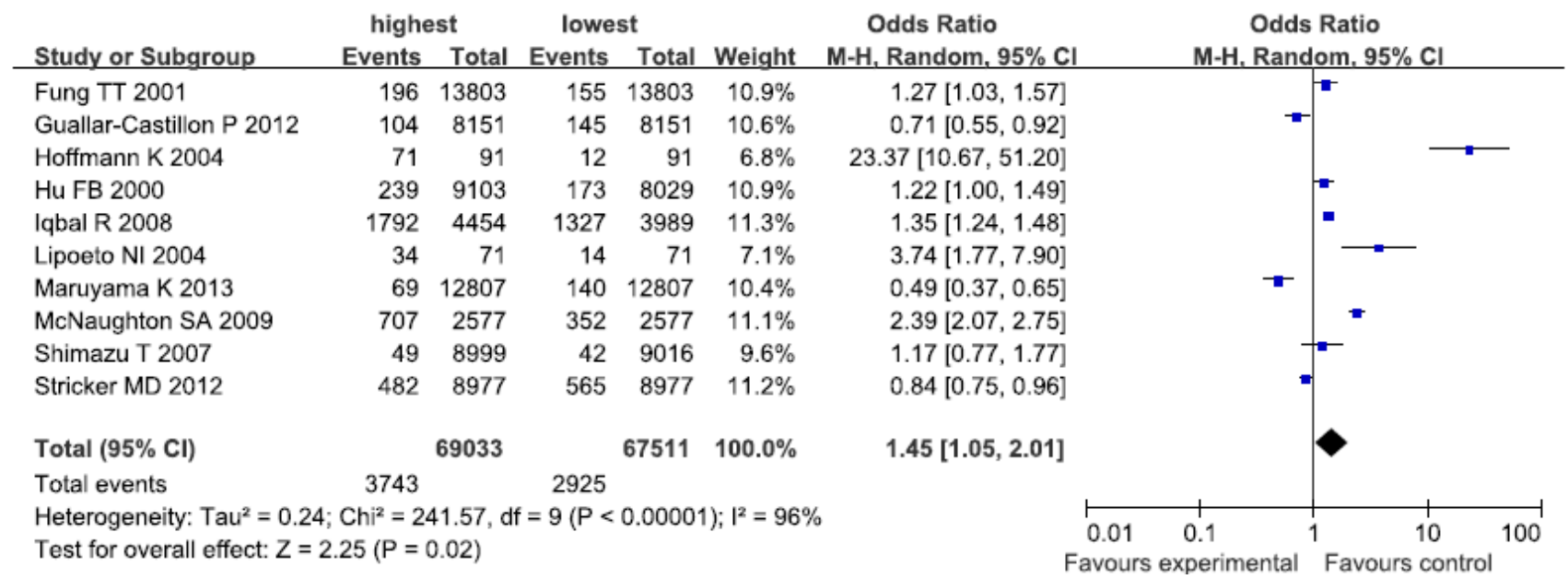

Figure 3. Forest plot of the highest compared with the lowest categories of intake of the unhealthy/Western-type dietary patterns and CHD risk.

\subsection{Alcohol Consumption}

The alcohol consumption was characterized by moderate intakes of wines, alcohol-containing beers, and white spirits. Nineteen studies (reporting twenty original studies) have identified moderate alcohol consumption. The data from nineteen studies were assessed using the random-effects model, and there was significant heterogeneity $\left(I^{2}=83 \%, p<0.00001\right)$. Figure 4 showed an obvious evidence of a decreased risk of CHD in the moderate drinking compared with non-drinking category intake of the alcohol consumption levels $(\mathrm{OR}=0.68 ; 95 \% \mathrm{CI}: 0.59,0.78 ; p<0.00001)$.

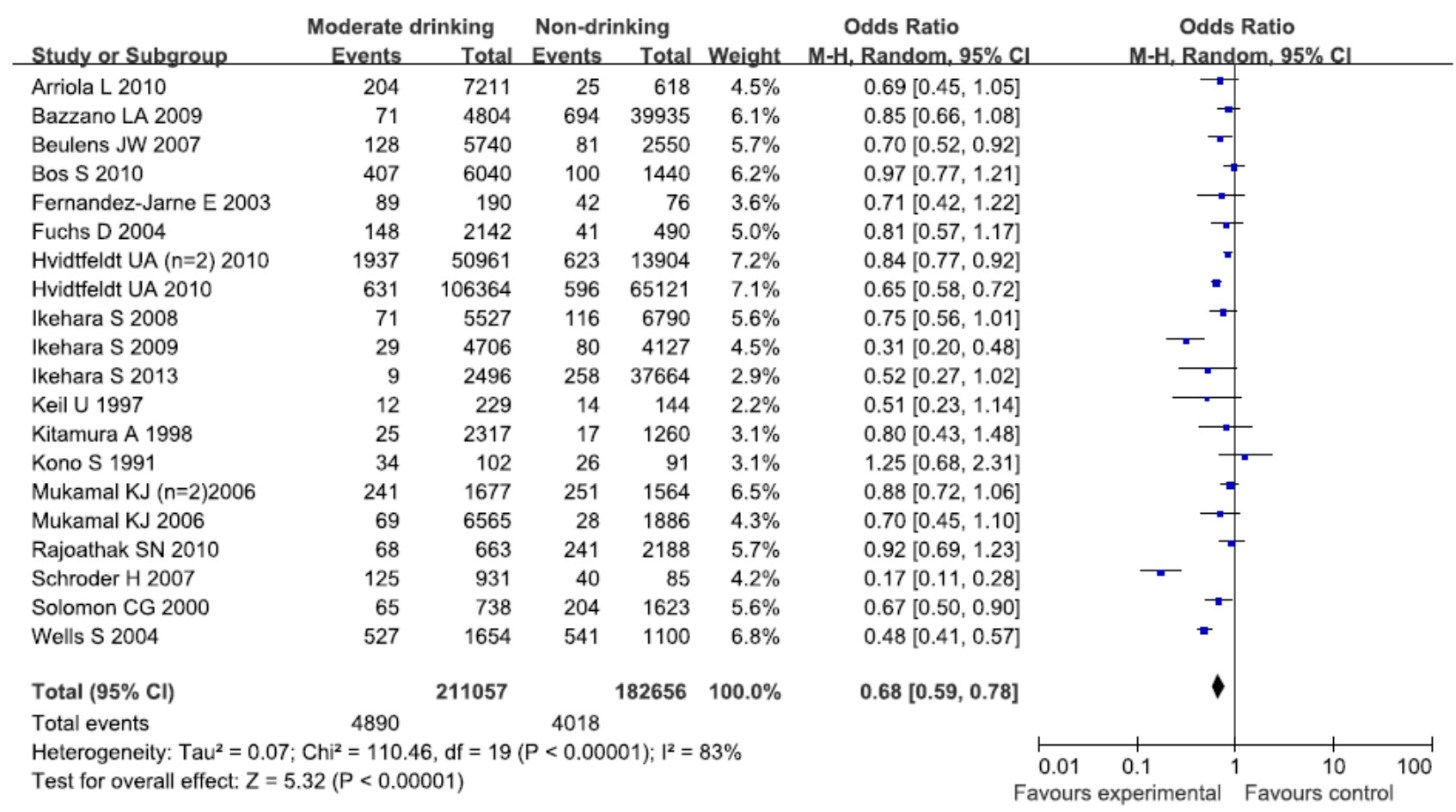

Figure 4. Forest plot of the moderate drinking compared with the non-drinking category of intake the alcohol-drinking pattern and CHD risk. 


\subsection{Publication Bias}

Inspection of funnel plots did not reveal evidence of asymmetry (Appendix A). Begg's tests for publication bias were not statistically significant (highest compared with lowest category: healthy/prudent dietary pattern, Begg's test $p=0.285$; unhealthy/Western-type dietary pattern, Begg's test $p=0.276$; and alcohol consumption, Begg's test $p=0.218$ ).

\subsection{Quality Assessment}

The quality of each study in terms of population and sampling methods, description of exposure and outcomes, and statistical adjustment of data, is summarized in Appendix B. Thirty-one of thirty-five studies received a score of six or higher on the Newcastle-Ottawa Quality assessment scale and were considered to be of high methodological quality [8,11,13-16,18-21,23,28,30-34,36-49].

\subsection{Sensitivity Analysis}

When the results were analyzed by removing non-American and non-European studies [17,22,30,36-38,41,44,47], the difference in the risk of CHD was shown in Western-type dietary pattern and alcohol consumption (Western-type: $\mathrm{OR}=1.53 ; 95 \% \mathrm{CI}: 1.05,2.22 ; p<0.01$; alcohol consumption: $\mathrm{OR}=0.68 ; 95 \% \mathrm{CI}: 0.51,0.80 ; p<0.05)$. When sample size $<10,000$ was removed [8,14,16-19,29,34,40-46], the difference in the risk of CHD was shown in Western-type dietary pattern $(\mathrm{OR}=1.77 ; 95 \% \mathrm{CI}: 1.08,2.28 ; p<0.01)$. Similarly, when the results were analyzed by removing the studies adjusted for total energy intake [16-18,20-23,28,30-32,34,39], the difference in the risk of CHD for those in the highest category compared with the lowest categories of Western-type dietary pattern was detected. Moreover, when the results were analyzed by removing the studies adjusted for sex, no difference in the risk of CHD was found. Finally, when the results were analyzed by removing case-control studies, the difference in the risk of CHD was shown in alcohol consumption $(\mathrm{OR}=0.74 ; 95 \% \mathrm{CI}: 0.66,0.83 ; p<0.01)$. As these variables have a strong effect on association between different dietary patterns and risk of CHD, their differences may partially explain the observed heterogeneity between studies (Table B2).

\section{Discussion}

Limited epidemiological research has reported the associations between dietary patterns and the risk of CHD. To our knowledge, this is the latest meta-analysis evaluating the evidence for dietary patterns and CHD risk. In the present study, we have an update on the earlier systematic review (Li et al., and Hou et al., 2014) [50,51] and further explore the association between moderate alcohol consumption and the risk of CHD. The results of this meta-analysis demonstrate that the healthy/prudent dietary patterns and moderate alcohol consumption may decrease the risk of CHD, whereas unhealthy/Western-type dietary patterns may increase the risk of CHD. Our findings have confirmed the associations between different dietary patterns and the risk of $\mathrm{CHD}$, and provided information that may be translated into public health action for primary prevention of CHD.

In our analyses, the healthy/prudent dietary patterns were associated with a reduced risk of CHD. Our results were in agreement with some previous studies, which reported an inverse association 
between healthy/prudent dietary patterns and the risk of CHD [11,23]. The apparently protective effect of vegetables, and fruits may be related to high concentration of antioxidant substances (e.g., vitamin $\mathrm{C}$, vitamin $\mathrm{E}$, and other carotenoids compounds). A previous meta-analysis of fruit and vegetables consumption and risk of CHD concluded that high intakes of fruit and vegetables were associated with a decreased risk of CHD [52]. Besides, several studies have also indicated that antioxidants such as vitamin $\mathrm{E}$ can slow the rate of oxidation, protecting endothelial cells and vascular [53], thereby reducing the risk of CHD. Furthermore, earlier studies have found that higher intake of folate may decrease the concentration of homocysteine, which may increase the risk of CHD [53,54]. Recently, Pereira et al. reported an inverse association between dietary fiber and the risk of CHD [55]. To our knowledge, the possible mechanism is that dietary fiber can modify blood lipid profiles, lower blood pressure, as well as reduce blood glucose concentrations by slowing intestinal absorption [56]. In addition, some clinical and biological investigations have also found that the micro- and macro-constituents of fruit and vegetables may decrease the risk of hypertension, dyslipidemia and diabetes, which are considered as having an important role in the development or progression of CHD [57,58].

The unhealthy/Western-type dietary patterns were associated with an increased risk of CHD in this meta-analysis. Our results were consistent with previous studies [17,19], which indicated that red meat and processed meat consumption were associated with an increased risk of CHD. To our knowledge, there are several plausible explanations for the positive association between Western-type dietary patterns and CHD risk. Firstly, high consumption of red and processed meat is associated with raised total cholesterol, LDL-cholesterol and blood pressure, and greater BMI [59]. As mentioned above, these metabolic changes are related with the risk factors for CHD. Secondly, high temperature commercial cooking or frying, commonly used in preparing processed meats, may generate heterocyclic amines or polycyclic aromatic hydrocarbons, which may increase the risk of CHD and DM [60,61]. Finally, processed meats contain a high content of salt, nitrates and their byproducts (e.g., peroxynitrite), which may be associated with an increased risk of CHD [62].

An inverse association was shown for moderate alcohol consumption and the risk of CHD in our analyses. Previously, a meta-analysis of alcohol consumption and the risk of CHD indicated that moderate alcohol-drinking ( $\leqslant 1.5$ drinks/day) was associated with a decreased risk of CHD [63]. In fact, alcohol consumption has been consistently considered an important risk for some chronic diseases, including hypertension and diabetes. Nevertheless, our results found the favorable effect of moderate alcohol consumption on the development of CHD. As we all know, moderate alcohol consumption can raise the concentration of serum high density lipoprotein cholesterol, which may protect against atheroma formation in coronary arteries [64,65]. In addition, it is also associated with the increased vascular wall prostacyclin, thus preventing thrombus formation in coronary arteries [66]. Furthermore, some studies have found that light to moderate alcohol consumption can lower the levels of fasting insulin [67], which is related to the decreased risk of CHD.

\section{Strengths and Limitations}

This meta-analysis has its own strengths and limitations. Firstly, this is the latest meta-analysis reporting the associations between dietary patterns and the risk of CHD. We not only have an update 
on an earlier systematic review ( $\mathrm{Li}$ et al. and Hou et al., 2014) [50,51], but also further explore the association between moderate alcohol consumption and the risk of CHD. Secondly, the cases of CHD were confirmed based on clinical manifestations, electrocardiogram, and coronary arteriography, avoiding misdiagnosis. Thirdly, no signs of publication bias were evident in the funnel plot, and the statistical test for publication bias was non-significant. However, some limitations should also be mentioned, when interpreting the results of this meta-analysis. Firstly, the principal limitation of this study was the use of potentially biased evidence. Moreover, there was an inconsistent adjustment for potential confounders among the included studies, and we did not exclude the possibility of confounding in this meta-analysis. As a result, the data included in our analyses might suffer from differing degrees of completeness and accuracy. Secondly, ten of thirty-six studies are case-control studies in this meta-analysis. Thus, selection bias is inevitable in our analyses.

\section{Conclusions}

In conclusion, results from this meta-analysis indicate that healthy/prudent dietary patterns and moderate alcohol consumption are associated with a decreased risk of CHD, while unhealthy/Western-type patterns are associated with an increased risk of CHD. In addition, these findings also suggest that a change of diet is essential for the prevention of CHD. Herein, it makes sense to elucidate the potential associations between dietary patterns and the risk of CHD, and provide scientific rationale for formulating dietary guidelines. Further studies are required to confirm the causal associations between dietary patterns and the risk of CHD.

\section{Acknowledgments}

This study was supported by provinces and the ministry of education (Grant NO.2014PYA002). The authors thank all participants from Department of Nutrition, Zhejiang Hospital, Zhejiang, China.

\section{Author Contributions}

X.-Y.Z., L.S. and P.-F.Z. conceived and designed the experiments. C.-J.S., X.-L.Y., D.L. and W.G. conducted research. X.-Y.Z. and L.S. analyzed data and wrote the paper. All authors read and approved the final manuscript.

\section{Conflicts of Interest}

The authors declared no conflict of interest. 


\section{Appendix A}

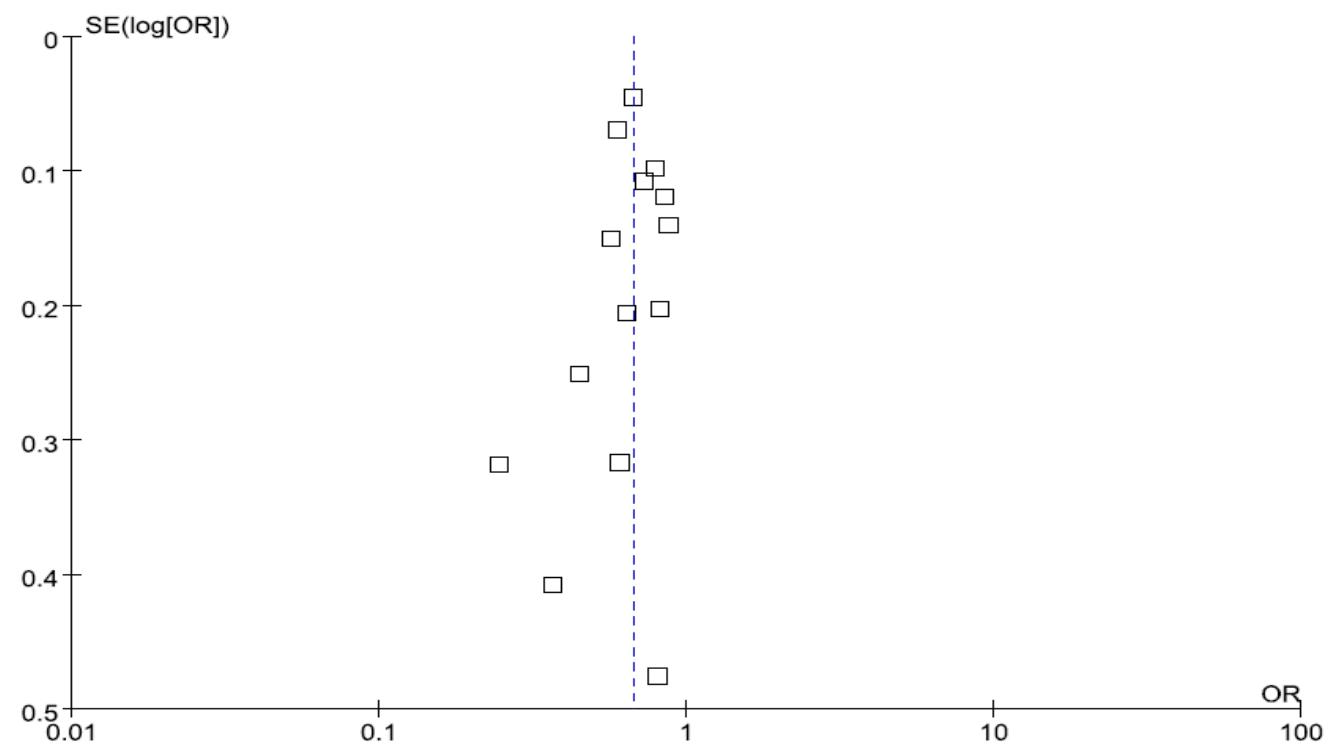

Figure A1. Funnel plots for coronary heart disease(CHD) in the highest compared with the lowest category of intake of the "healthy" dietary pattern in all studies.

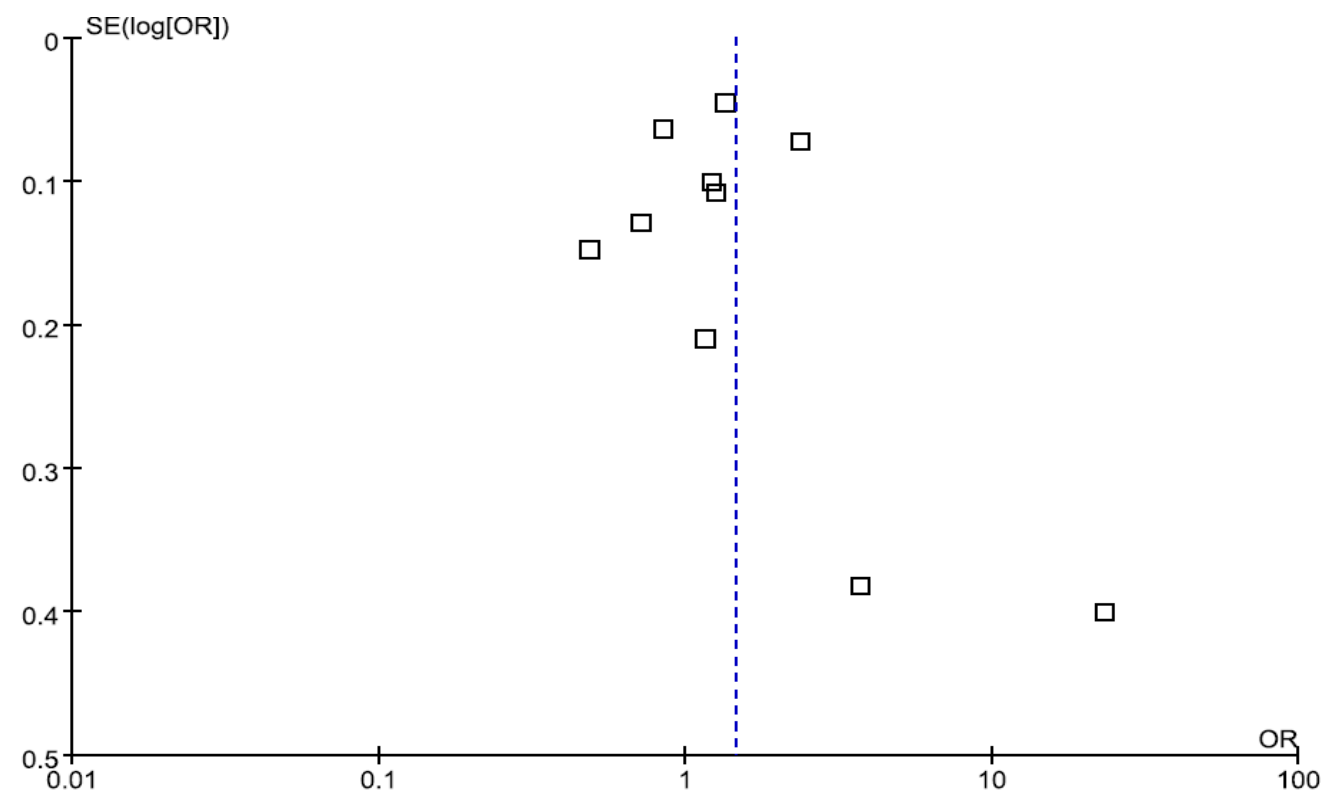

Figure A2. Funnel plots for CHD in the highest compared with the lowest category of intake of the "Western-type" dietary pattern in all studies. 


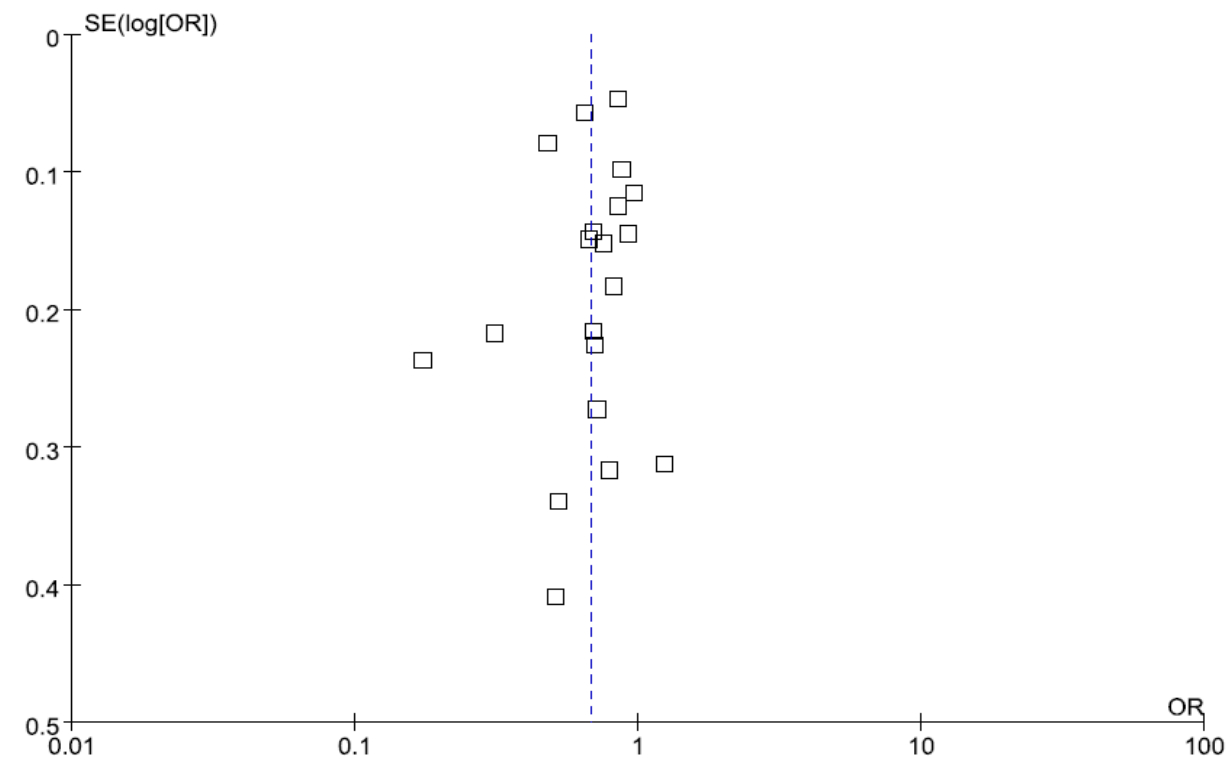

Figure A3. Funnel plots for CHD in the moderate drinking compared with non-drinking category intake of "alcohol consumption" pattern in all studies.

\section{Appendix B}

Table B1. Assessment of study quality.

\begin{tabular}{|c|c|c|c|c|c|c|c|c|c|c|}
\hline \multirow{2}{*}{ Studies } & \multicolumn{4}{|c|}{ Selection } & \multicolumn{3}{|c|}{ Comparability } & \multicolumn{2}{|c|}{ Outcome } & \multirow{2}{*}{ Score } \\
\hline & 1 & 2 & 3 & 4 & $5 \mathbf{A}$ & $5 B$ & 6 & 7 & 8 & \\
\hline \multicolumn{11}{|l|}{ Cohort } \\
\hline Fung et al., 2001 [11] & & $*$ & $*$ & $*$ & $*$ & $*$ & $*$ & $*$ & $*$ & $* * * * * * * *$ \\
\hline Fitzgerald et al., 2012 [20] & $*$ & $*$ & $*$ & $*$ & $*$ & & $*$ & $*$ & $*$ & $* * * * * * * *$ \\
\hline Guallar-Castillón et al., 2012 [28] & $*$ & & $*$ & $*$ & $*$ & & $*$ & $*$ & $*$ & $* * * * * * *$ \\
\hline Hu et al., 2000 [23] & $*$ & $*$ & $*$ & $*$ & $*$ & $*$ & $*$ & $*$ & $*$ & $* * * * * * * * *$ \\
\hline $\begin{array}{l}\text { Martínez-Gonzlez et al., } \\
\qquad 2011[21]\end{array}$ & $*$ & $*$ & $*$ & $*$ & $*$ & & $*$ & & $*$ & $* * * * * * *$ \\
\hline Maruyama et al., 2013 [22] & $*$ & & $*$ & & $*$ & & $*$ & $*$ & & $* * * * *$ \\
\hline Osler et al., 2002 [8] & $*$ & $*$ & $*$ & $*$ & $*$ & $*$ & $*$ & $*$ & $*$ & $* * * * * * * * *$ \\
\hline Shimazu et al., 2007 [30] & $*$ & $*$ & $*$ & $*$ & $*$ & & $*$ & $*$ & $*$ & $* * * * * * * *$ \\
\hline Stricker et al., 2012 [15] & & $*$ & $*$ & $*$ & $*$ & $*$ & $*$ & $*$ & $*$ & $* * * * * * * *$ \\
\hline Tucker et al., 2005 [18] & $*$ & & $*$ & $*$ & $*$ & & & $*$ & $*$ & $* * * * * *$ \\
\hline Weikert et al., 2005 [16] & $*$ & $*$ & $*$ & $*$ & $*$ & $*$ & $*$ & $*$ & $*$ & $* * * * * * * * *$ \\
\hline McNaughton et al., 2009 [19] & $*$ & & $*$ & $*$ & $*$ & $*$ & $*$ & $*$ & $*$ & $* * * * * * * *$ \\
\hline Arriola et al., 2010 [31] & $*$ & & $*$ & $*$ & $*$ & & $*$ & $*$ & $*$ & $* * * * * * * *$ \\
\hline Solomon et al., 2000 [46] & & $*$ & $*$ & $*$ & $*$ & $*$ & $*$ & $*$ & $*$ & $* * * * * * * *$ \\
\hline Beulens et al., 2007 [32] & $*$ & $*$ & $*$ & $*$ & $*$ & & $*$ & $*$ & $*$ & $* * * * * * * *$ \\
\hline Bos et al., 2010 [33] & $*$ & $*$ & $*$ & $*$ & $*$ & $*$ & $*$ & $*$ & $*$ & $* * * * * * * * *$ \\
\hline
\end{tabular}


Table B1. Cont.

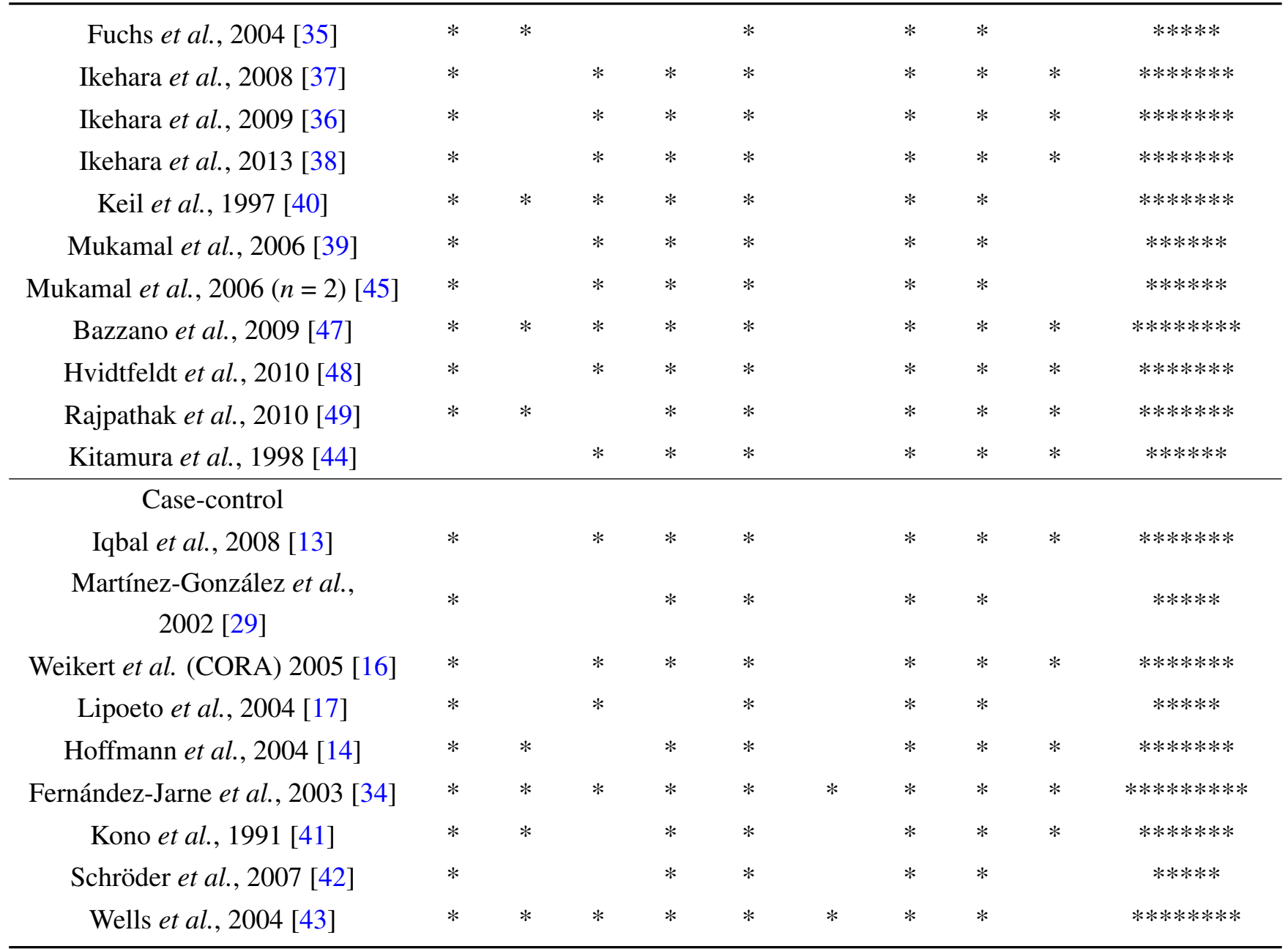

* For case-control studies, 1 , indicates cases independently validated; 2 , cases are representative of population; 3 , community controls; 4 , controls have no history of blood pressure disease; $5 \mathrm{~A}$, study controls for age; 5B, study controls for additional factor (s); 6, ascertainment of exposure by blinded interview or record; 7, same method of ascertainment used for cases and controls; and 8, non response rate the same for cases and controls. For cohort studies, 1 indicates exposed cohort truly representative; 2, non exposed cohort drawn from the same community; 3, ascertainment of exposure; 4, outcome of interest not present at start; $5 \mathrm{~A}$, cohorts comparable on basis of age; $5 \mathrm{~B}$, cohorts comparable on other factor(s); 6 , quality of outcome assessment; 7, follow-up long enough for outcomes to occur; and 8 , complete accounting for cohorts. 
Table B2. Dietary patterns, alcohol consumption and coronary heart disease: sensitivity analysis.

\begin{tabular}{ccccc}
\hline $\begin{array}{c}\text { Study } \\
\text { Characteristic }\end{array}$ & Category & $\begin{array}{c}\text { Healthy Dietary } \\
\text { Pattern }(\mathbf{9 5 \%} \text { CI) }\end{array}$ & $\begin{array}{c}\text { Western-Style Dietary } \\
\text { Pattern }(\mathbf{9 5 \%} \text { CI) }\end{array}$ & $\begin{array}{c}\text { Alcohol } \\
\text { Consumption } \\
\text { (95\% CI) }\end{array}$ \\
\hline \multirow{2}{*}{ Age } & $>50$ & $0.65(0.56,0.76)$ & $1.31(0.91,1.88)$ & $0.72(0.60,0.86)$ \\
& $<50$ & $0.75(0.63,0.90)$ & $1.49(0.90,2.45)$ & $0.59(0.45,0.79)$ \\
\hline \multirow{2}{*}{ Sample size } & Large $(>10,000)$ & $0.71(0.64,0.79)$ & $1.21(0.87,1.67)$ & $0.72(0.62,0.83)$ \\
& Small $(<10,000)$ & $0.56(0.37,0.86)$ & $\mathbf{1 . 7 7}(\mathbf{1 . 0 8 , 2 . 8 8 )}$ & $0.64(0.46,0.87)$ \\
\hline \multirow{2}{*}{ Race } & White & $0.67(0.58,0.77)$ & $\mathbf{1 . 5 3 ( 1 . 0 5 , 2 . 2 2 )}$ & $\mathbf{0 . 6 8}(\mathbf{0 . 5 1 , 0 . 8 0})$ \\
& Asian and Other & $0.75(0.60,0.92)$ & $1.15(0.63,2.11)$ & $0.76(0.57,1.06)$ \\
\hline \multirow{2}{*}{ Study design } & Case-control & $0.48(0.28,0.84)$ & $4.49(0.73,25.75)$ & $0.51(0.37,1.07)$ \\
& Cohort & $0.72(0.64,0.81)$ & $1.08(0.79,1.48)$ & $\mathbf{0 . 7 4}(\mathbf{0 . 6 6 , 0 . 8 3 )}$ \\
\hline \multirow{2}{*}{ Total energy } & Adjusted & $0.67(0.56,0.80)$ & $1.05(0.73,1.51)$ & $0.78(0.68,0.90)$ \\
& Unadjusted & $0.65(0.61,0.70)$ & $\mathbf{1 . 9 9}(\mathbf{1 . 2 7}, \mathbf{3 . 1 3})$ & $0.76(0.55,0.78)$ \\
\hline
\end{tabular}

\section{References}

1. Mackay, J.; Mensah, G. The Atlas of Heart Disease and Stroke. Available via World Health Organization. Available online: http://www.who.int/cardiovascular_diseases/resources/atlas/en/ (accessed on 29 September 2004).

2. Levi, F.; Lucchini, F.; Negri, E.; La Vecchia, C. Trends in mortality from cardiovascular and cerebrovascular diseases in Europe and other areas of the world. Heart 2002, 88, 119-124. [CrossRef] [PubMed]

3. Xu, J.; Lee, E.T.; Peterson, L.E.; Devereux, R.B.; Rhoades, E.R.; Umans, J.G.; Best, L.G.; Howard, W.J.; Paranilam, J.; Howard, B.V. Differences in risk factors for coronary heart disease among diabetic and nondiabetic individuals from a population with high rates of diabetes: The Strong Heart Study. J. Clin. Endocrinol. Metab. 2012, 97, 3766-3767. [CrossRef] [PubMed]

4. He, J.; Gu, D.; Wu, X.; Reynolds, K.; Duan, X.; Yao, C.; Wang, J.; Chen, C.S.; Chen, J.; Wildman, R.P.; et al. Major causes of death among men and women in China. N. Engl. J. Med. 2005, 353, 1124-1134. [CrossRef] [PubMed]

5. World Health Organization. World Health Statistics Annual, 2010. Available via World Health Organization. Available online: http://www.who.int/whosis/whostat/2010/en/index.html (accessed on 13 June 2011).

6. Frankel, S.; Elwood, P.; Sweetnam, P.; Yarnell, J.; Smith, G.D. Birthweight, body-mass index in middle age, and incident coronary heart disease. Lancet 1996, 348, 1478-1480. [CrossRef]

7. McKeigue, P.M.; Lithell, H.O.; Leon, D.A. Glucose tolerance and resistance to insulin-stimulated glucose uptake in mean aged 70 years in relation to size at birth. Diabetologia 1998, 41, 1133-1138. [CrossRef] [PubMed] 
8. Osler, M.; Helms Andreasen, A.; Heitmann, B.; Høidrup, S.; Gerdes, U.; Mørch Jørgensen, L.; Schroll, M. Food intake patterns and risk of coronary heart disease: A prospective cohort study examining the use of traditional scoring techniques. Eur. J. Clin. Nutr. 2002, 56, 568-574. [CrossRef] [PubMed]

9. Lancaster, K.J.; Smiciklas-Wright, H.; Weitzel, L.B.; Mitchell, D.C.; Friedmann, J.M.; Jensen, G.L. Hypertension-related dietary patterns of rural older adults. Prev. Med. 2004, 38, 812-818. [CrossRef] [PubMed]

10. Hu, F.B. Dietary pattern analysis: A new direction in nutritional epidemiology. Curr. Opin. Lipidol. 2002, 13, 3-9. [CrossRef] [PubMed]

11. Fung, T.T.; Willett, W.C.; Stampfer, M.J.; Manson, J.E.; Hu, F.B. Dietary patterns and the risk of coronary heart disease in women. Arch. Intern. Med. 2001, 161, 1857-1862. [CrossRef] [PubMed]

12. Guo, J.; Li, W.; Wang, Y.; Chen, T.; Teo, K.; Liu, L.S.; Yusuf, S. Influence of dietary patterns on the risk of acute myocardial infarction in China population: The INTERHEART China study. Chin. Med. J. (Engl.) 2013, 126, 464-470. [PubMed]

13. Iqbal, R.; Anand, S.; Ounpuu, S.; Islam, S.; Zhang, X.; Rangarajan, S.; Chifamba, J.; Al-Hinai, A.; Keltai, M.; Yusuf, S.; et al. Dietary patterns and the risk of acute myocardial infarction in 52 countries: Results of the INTERHEART study. Circulation 2008, 118, 1929-1937. [CrossRef] [PubMed]

14. Hoffmann, K.; Zyriax, B.C.; Boeing, H.; Windler, E. A dietary pattern derived to explain biomarker variation is strongly associated with the risk of coronary artery disease. Am. J. Clin. Nutr. 2004, 80, 633-640. [PubMed]

15. Stricker, M.D.; Onland-Moret, N.C.; Boer, J.M.; van der Schouw, Y.T.; Verschuren, W.M.; May, A.M.; Peeters, P.H.; Beulens, J.W. Dietary patterns derived from principal component- and k-means cluster analysis: Long-term association with coronary heart disease and stroke. Nutr. Metab. Cardiovasc. Dis. 2013, 23, 250-256. [CrossRef] [PubMed]

16. Weikert, C.; Hoffmann, K.; Dierkes, J.; Zyriax, B.C.; Klipstein-Grobusch, K.; Schulze, M.B.; Jung, R.; Windler, E.; Boeing, H. A homocysteine metabolism-related dietary pattern and the risk of coronary heart disease in two independent German study populations. J. Nutr. 2005, 135, 1981-1988. [PubMed]

17. Lipoeto, N.I.; Agus, Z.; Oenzil, F.; Wahlqvist, M.; Wattanapenpaiboon, N. Dietary intake and the risk of coronary heart disease among the coconut-consuming Minangkabau in West Sumatra, Indonesia. Asia Pac. J. Clin. Nutr. 2004, 13, 377-378. [PubMed]

18. Tucker, K.L.; Hallfrisch, J.; Qiao, N.; Muller, D.; Andres, R.; Fleg, J.L. The combination of high fruit and vegetable and low saturated fat intakes is more protective against mortality in aging men than is either alone: The Baltimore Longitudinal Study of Aging. J. Nutr. 2005, 135, 556-561. [PubMed]

19. McNaughton, S.A.; Mishra, G.D.; Brunner, E.J. Food patterns associated with blood lipids are predictive of coronary heart disease: The Whitehall II study. Br. J. Nutr. 2009, 102, 619-624. [CrossRef] [PubMed] 
20. Fitzgerald, K.C.; Chiuve, S.E.; Buring, J.E.; Ridker, P.M.; Glynn, R.J. Comparison of associations of adherence to a Dietary Approaches to Stop Hypertension (DASH)-style diet with risks of cardiovascular disease and venous thromboembolism. J. Thromb. Haemost. 2012, 10, 189-198. [CrossRef] [PubMed]

21. Martinez-Gonzalez, M.A.; Garcia-Lopez, M.; Bes-Rastrollo, M.; Toledo, E.; Martínez-Lapiscina, E.H.; Delgado-Rodriguez, M.; Vazquez, Z.; Benito, S.; Beunza, J.J. Mediterranean diet and the incidence of cardiovascular disease: A Spanish cohort. Nutr. Metab. Cardiovasc. Dis. 2011, 21, 237-244. [CrossRef] [PubMed]

22. Maruyama, K.; Iso, H.; Date, C.; Kikuchi, S.; Watanabe, Y.; Wada, Y.; Inaba, Y.; Tamakoshi, A. Dietary patterns and risk of cardiovascular deaths among middle-aged Japanese: JACC Study. Nutr. Metab. Cardiovasc. Dis. 2013, 23, 519. [CrossRef] [PubMed]

23. Hu, F.B.; Rimm, E.B.; Stampfer, M.J.; Ascherio, A.; Spiegelman, D.; Willett, W.C. Prospective study of major dietary patterns and risk of coronary heart disease in men. Am. J. Clin. Nutr. 2000, 72, 912-921. [PubMed]

24. US Government. Alcoholic Beverages: Dietary Guidelines for Americans 2005; US Government Printing Office: Washington, DC, USA, 2005.

25. Stang, A. Critical evaluation of the Newcastle-Ottawa scale for the assessment of the quality of nonrandomized studies in meta-analyses. Eur. J. Epidemiol. 2010, 25, 603-605. [CrossRef] [PubMed]

26. Higgins, J.P.; Thompson, S.G.; Deeks, J.J.; Altman, D.G. Measuring inconsistency in meta-analyses. BMJ 2003, 327, 557-560. [CrossRef] [PubMed]

27. Begg, C.B.; Mazumdar, M. Operating characteristics of a rank correlation test for publication bias. Biometrics 1994, 50, 1088-1101. [CrossRef] [PubMed]

28. Guallar-Castillon, P.; Rodriguez-Artalejo, F.; Tormo, M.J.; Sánchez, M.J.; Rodríguez, L.; Quirós, J.R.; Navarro, C.; Molina, E.; Martínez, C.; Marín, P.; et al. Major dietary patterns and risk of coronary heart disease in middle-aged persons from a Mediterranean country: The EPIC-Spain cohort study. Nutr. Metab. Cardiovasc. Dis. 2012, 22, 192-199. [CrossRef] [PubMed]

29. Martinez-Gonzalez, M.A.; Fernandez-Jarne, E.; Serrano-Martinez, M.; Marti, A.; Martinez J, A.; Martin-Moreno, J.M. Mediterranean diet and reduction in the risk of a first acute myocardial infarction: An operational healthy dietary score. Eur. J. Nutr. 2002, 41, 153-160. [CrossRef] [PubMed]

30. Shimazu, T.; Kuriyama, S.; Hozawa, A.; Ohmori, K.; Sato, Y.; Nakaya, N.; Nishino, Y.; Tsubono, Y.; Tsuji, I. Dietary patterns and cardiovascular disease mortality in Japan: A prospective cohort study. Int. J. Epidemiol. 2007, 36, 600-609. [CrossRef] [PubMed]

31. Arriola, L.; Martinez-Camblor, P.; Larranaga, N.; Basterretxea, M.; Amiano, P.; Moreno-Iribas, C.; Carracedo, R.; Agudo, A.; Ardanaz, E.; Barricarte, A.; et al. Alcohol intake and the risk of coronary heart disease in the Spanish EPIC cohort study. Heart 2010, 96, 124-130. [CrossRef] [PubMed]

32. Beulens, J.W.; Rimm, E.B.; Ascherio, A.; Spiegelman, D.; Hendriks, H.F.; Mukamal, K.J. Alcohol consumption and risk for coronary heart disease among men with hypertension. Ann. Intern. Med. 2007, 146, 10-19. [CrossRef] [PubMed] 
33. Bos, S.; Grobbee, D.E.; Boer, J.M.; Verschuren, W.M.; Beulens, J.W. Alcohol consumption and risk of cardiovascular disease among hypertensive women. Eur. J. Cardiovasc. Prev. Rehabil. 2010, 17, 119-126. [CrossRef] [PubMed]

34. Fernandez-Jarne, E.; Martinez-Losa, E.; Serrano-Martinez, M.; Prado-Santamaria, M.; Brugarolas-Brufau, C.; Martinez-Gonzalez, M.A. Type of alcoholic beverage and first acute myocardial infarction: A case-control study in a Mediterranean country. Clin. Cardiol. 2003, 26, 313-318. [CrossRef] [PubMed]

35. Fuchs, F.D.; Chambless, L.E.; Folsom, A.R.; Eigenbrodt, M.L.; Duncan, B.B.; Gilbert, A.; Szklo, M. Association between alcoholic beverage consumption and incidence of coronary heart disease in whites and blacks: The Atherosclerosis Risk in Communities Study. Am. J. Epidemiol. 2004, 160, 466-474. [CrossRef] [PubMed]

36. Ikehara, S.; Iso, H.; Yamagishi, K.; Yamamoto, S.; Inoue, M.; Tsugane, S. Alcohol consumption, social support, and risk of stroke and coronary heart disease among Japanese men: The JPHC Study. Alcohol. Clin. Exp. Res. 2009, 33, 1025-1032. [CrossRef] [PubMed]

37. Ikehara, S.; Iso, H.; Toyoshima, H.; Date, C.; Yamamoto, A.; Kikuchi, S.; Kondo, T.; Watanabe, Y.; Koizumi, A.; Wada, Y.; et al. Alcohol consumption and mortality from stroke and coronary heart disease among Japanese men and women: The Japan collaborative cohort study. Stroke 2008, 39 , 2936-2942. [CrossRef] [PubMed]

38. Ikehara, S.; Iso, H.; Yamagishi, K.; Kokubo, Y.; Saito, I.; Yatsuya, H.; Inoue, M.; Tsugane, S. Alcohol consumption and risk of stroke and coronary heart disease among Japanese women: The Japan Public Health Center-based prospective study. Prev. Med. 2013, 57, 505-510. [CrossRef] [PubMed]

39. Mukamal, K.J.; Chiuve, S.E.; Rimm, E.B. Alcohol consumption and risk for coronary heart disease in men with healthy lifestyles. Arch. Intern. Med. 2006, 166, 2145-2150. [CrossRef] [PubMed]

40. Keil, U.; Chambless, L.E.; Doring, A.; Filipiak, B.; Stieber, J. The relation of alcohol intake to coronary heart disease and all-cause mortality in a beer-drinking population. Epidemiology 1997, 8, 150-156. [CrossRef] [PubMed]

41. Kono, S.; Handa, K.; Kawano, T.; Hiroki, T.; Ishihara, Y.; Arakawa, K. Alcohol intake and nonfatal acute myocardial infarction in Japan. Am. J. Cardiol. 1991, 68, 1011-1014. [CrossRef]

42. Schroder, H.; Masabeu, A.; Marti, M.J.; Cols, M.; Lisbona, J.M.; Romagosa, C.; Carión, T.; Vilert, E.; Marrugat, J. Myocardial infarction and alcohol consumption: A population-based case-control study. Nutr. Metab. Cardiovasc. Dis. 2007, 7, 609-615. [CrossRef] [PubMed]

43. Wells, S.; Broad, J.; Jackson, R. Alcohol consumption and its contribution to the burden of coronary heart disease in middle-aged and older New Zealanders: A population-based case-control study. N. Z. Med. J. 2004, 117, 793.

44. Kitamura, A.; Iso, H.; Sankai, T.; Naito, Y.; Sato, S.; Kiyama, M.; Okamura, T.; Nakagawa, Y.; Iida, M.; Shimamoto, Y.; et al. Alcohol intake and premature coronary heart disease in urban Japanese men. Am. J. Epidemiol. 1998, 147, 59-65. [CrossRef] [PubMed] 
45. Mukamal, K.J.; Chung, H.; Jenny, N.S.; Kuller, L.H.; Longstreth, W.T.; Mittleman, M.A.; Burke, G.L.; Cushman, M.; Psaty, B.M.; Siscovick, D.S. Alcohol consumption and risk of coronary heart disease in older adults: The Cardiovascular Health Study. J. Am. Geriatr. Soc. 2006, 54, 30-37. [CrossRef] [PubMed]

46. Solomon, C.G.; Hu, F.B.; Stampfer, M.J.; Colditz, G.A.; Speizer, F.E.; Rimm, E.B.; Willett, W.C.; Manson, J.E. Moderate alcohol consumption and risk of coronary heart disease among women with type 2 diabetes mellitus. Circulation 2000, 102, 494-499. [CrossRef] [PubMed]

47. Bazzano, L.A.; Gu, D.; Reynolds, K.; Chen, J.; Wu, X.; Chen, C.S.; Duan, X.; Chen, J.; He, J. Alcohol consumption and risk of coronary heart disease among Chinese men. Int. J. Cardiol. 2009, 135, 78-85. [CrossRef] [PubMed]

48. Hvidtfeldt, U.A.; Tolstrup, J.S.; Jakobsen, M.U.; Heitmann, B.L.; Grønbaek, M.; O’Reilly, E.; Bälter, K.; Goldbourt, U.; Hallmans, G.; Knekt, P.; et al. Alcohol intake and risk of coronary heart disease in younger, middle-aged, and older adults. Circulation 2010, 121, 1589-1597. [CrossRef] [PubMed]

49. Rajpathak, S.N.; Freiberg, M.S.; Wang, C.; Wylie-Rosett, J.; Wildman, R.P.; Rohan, T.E.; Robinson, J.G.; Liu, S.; Wassertheil-Smoller, S. Alcohol consumption and the risk of coronary heart disease in postmenopausal women with diabetes: Women's Health Initiative Observational Study. Eur. J. Nutr. 2010, 49, 211-218. [CrossRef] [PubMed]

50. Hou, L.; Li, F.; Wang, Y.; Ou, Z.; Xu, D.; Tan, W.; Dai, A. Association between dietary patterns and coronary heart disease: A meta-analysis of prospective cohort studies. Int. J. Clin. Exp. Med. 2015, 8, 781-790. [PubMed]

51. Li, F.; Hou, L.N.; Chen, W.; Chen, P.L.; Lei, C.Y.; Wei, Q.; Tan, W.L.; Zheng, S.B. Associations of dietary patterns with the risk of all-cause, CVD and stroke mortality: A meta-analysis of prospective cohort studies. Br. J. Nutr. 2014, 113, 16-24. [CrossRef] [PubMed]

52. Dauchet, L.; Amouyel, P.; Hercberg, S.; Dallongeville, J. Fruit and vegetable consumption and risk of coronary heart disease: A meta-analysis of cohort studies. J. Nutr. 2006, 136, 2588-2593. [PubMed]

53. Clarke, R. Lowering blood homocysteine with folic acid based supplements: Meta-analysis of randomized trials. Indian Heart J. 2000, 52 (Suppl. S7), S59-S64. [PubMed]

54. Elkelboom, J.W.; Lonn, E.; Genest, J., Jr.; Hankey, G.; Yusuf, S. Homocysteine and cardiovascular disease: A critical review of the epidemiologic evidence. Ann. Intern. Med. 1999, 131, 363-375. [CrossRef]

55. Pereira, M.A.; O’ Reilly, E.; Augustsson, K.; Fraser, G.E.; Goldbourt, U.; Heitmann, B.L.; Hallmans, G.; Knekt, P.; Liu, S.; Pietinen, P.; et al. Dietary fiber and risk of coronary heart disease: A pooled analysis of cohort studies. Arch. Intern. Med. 2004, 164, 370-376. [CrossRef] [PubMed]

56. Wu, Y.; Qian, Y.; Pan, Y.; Li, P.; Yang, J.; Ye, X.; Xu, G. Association between dietary fiber intake and risk of coronary heart disease: A meta-analysis. Clin. Nutr. 2015, 34, 603-611. [CrossRef] [PubMed]

57. Van Duyn, M.A.; Pivonka, E. Overview of the health benefits of fruit and vegetable consumption for the dietetics professional: Selected literature. J. Am. Diet. Assoc. 2000, 10, 1511-1521. [CrossRef] 
58. Bazzano, L.A.; Serdual, M.K.; Liu, S. Dietary intake of fruits and vegetables and risk of cardiovascular disease. Curr. Atheroscler. Rep. 2003, 5, 492-499. [CrossRef] [PubMed]

59. Steffen, L.M.; Kroenke, C.H.; Yu, X.; Pereira, M.A.; Slattery, M.L.; Van Horn, L.; Gross, M.D.; Jacobs, D.R., Jr.; et al. Associations of plant food, dairy product, and meat intakes with 15-y incidence of elevated blood pressure in young black and white adults: The Coronary Artery Risk Development in Young Adults (CARDIA) Study. Am. J. Clin. Nutr. 2005, 82, 1169-1177. [PubMed]

60. Lakshmi, V.M.; Schut, H.A.; Zenser, T.V. 2-Nitrosoamino-3-methylimidazo [4,5-f] quinoline activated by the inflammatory response forms nucleotide adducts. Food Chem. Toxicol. 2005, 43, 1607-1617. [CrossRef] [PubMed]

61. Bogen, K.T.; Keating, G.A. U.S. dietary exposures to heterocyclic amines. J. Expo. Anal. Environ. Epidemiol. 2001, 11, 155-168. [CrossRef] [PubMed]

62. He, F.J.; MacGregor, G.A. Effect of modest salt reduction on blood pressure: A meta-analysis ofrandomized trials. Implications for public health. J. Hum. Hypertens. 2002, 16, 761-770. [CrossRef] [PubMed]

63. Rimm, E.B.; Williams, P.; Fosher, K.; Criqui, M.; Stampfer, M.J. Moderate alcohol intake and lower risk of coronary heart disease: Meta-analysis of effects on lipids and haemostatic factors. BMJ 1999, 319, 1523-1528. [CrossRef] [PubMed]

64. Castelli, W.P.; Doyle, J.T.; Gordon, T.; Hames, C.G.; Hjortland, M.C.; Hulley, S.B.; Kagan, A.; Zukel, W.J. Alcohol and blood lipids. The Cooperative Lipoprotein Phenotyping Study. Lancet 1977, 2, 153-155. [CrossRef]

65. Hulley, S.B.; Gordon, S. Alcohol and high-density lipoprotein cholesterol: Causal inference from diverse study designs. Circulation 1981, 64, 57-63.

66. Moncada, S.; Randomski, N.W. The problems and the promise of prostaglandin influences in atherogenesis. Ann. N. Y. Acad. Sci. 1985, 454, 121-130. [CrossRef] [PubMed]

67. Lazarus, R.; Sparrow, D.; Weiss, S.T. Alcohol intake and insulin levels: The Normative Aging Study. Am. J. Epidemiol. 1997, 145, 909-916. [CrossRef] [PubMed]

(C) 2015 by the authors; licensee MDPI, Basel, Switzerland. This article is an open access article distributed under the terms and conditions of the Creative Commons Attribution license (http://creativecommons.org/licenses/by/4.0/). 